\section{Prevalence OF ACANTHOCEPHALANS IN BIRDS OF PREY FROM THE MIDDLE EAST AND REPORT OF TWO CLINICAL CASES}

\author{
TARELLO W.*
}

Sir,

Acanthocephalan ("spiny-headed") worms are enteroparasites of birds characterised by a retractile proboscis armed with rows of thorns (Lacina \& Bird, 2000). They penetrate the intestinal mucosa with the proboscis causing inflammation and nodules (Heidenreich, 1997). An arthropod (insect or mollusk) becomes the first intermediate host ingesting acanthocephalan eggs that contain the larvae (acanthor). Small vertebrates, such as the common and pigmy shrews (Sorex araneus and $S$. minutus) act as paratenic hosts that cumulate encysted larval stages in their bodies, eventually passing the infestation to the definitive host, the bird of prey, when ingested (Cooper, 2005). Several species, including Centrorbynchus globocaudatus in the peregrine falcon (Heidenreich, 1997), have been described in birds of prey. However, little is known about the pathogenicity of thorny-headed worms (Cooper, 2005) and their prevalence in raptors from the Middle East.

Microscopic examination of 3,988 fresh fecal samples from captive falcons from Kuwait $(n=1,706)$ and Dubai ( $n=2,282$ ) was performed between 2003 and 2006. Only two cases $(0.05 \%)$ of infestation due to acanthocephalans were recorded, one in Kuwait and one in Dubai, both in saker falcons (Falco cherrug) showing compatible clinical signs (Table I) and high number of acanthocephalan eggs (Fig. 1), 52-60 × 20-30 $\mu \mathrm{m}$ in size, easily distinguishable due to their dark pigmentation. Eggs contain a small larva complete with hooked proboscis.

Although Acanthocephala are generally considered to have the lowest prevalence amongst the endoparasites of birds of prey (Cooper, 2005), as confirmed in the present report $(0.05 \%)$ from the Middle East, $15 \%$ of Falconiformes investigated in Spain were found infested with acanthocephalans (Illescas et al., 1993). In Catalonia alone, $6.7 \%$ of raptors (one Buteo buteo, two Circaetus gallicus and five Falco tinnunculus) harboured acanthocephalans (Ferrer et al., 2004). But in Galicia (northwest Spain), only one bird out of 285 was infested (Sanmartin et al., 2004). In raptors from Poland

\footnotetext{
* DVM, MRCVS, Studio Veterinario Spina, C.P. 1644, 06129 Perugia, Italy.

Tel.: + 390755052204 - E-mail: wtarello@yahoo.it
}

a high prevalence $(4.1 \%)$ was reported as well (Furmaga, 1957) while only $1.1 \%$ of Falconiformes were found infested in Germany (Krone, 2000).

Apparently, the parasite prevalence greatly varies in different regions and countries. A possible explanation could be the fact that intermediate hosts, such as grasshoppers, and paratenic hosts such as lizards and snakes, are more abundant in some areas, i.e. the Mediterranean (Cooper, 2005). Moreover, it seems that there is a direct link between the percentage of shrews (paratenic hosts) in the diet of a raptor species and the incidence of infestation (Michalek, 1984).

The record of compatible clinical signs (Table I) indicates that intestinal symptoms are usually associated with the parasitosis. In some studies, acanthocephalans were present in extremely high numbers without any apparent incidence on the mortality rate (Lacina \& Bird, 2000). However, these worms were reported in $57 \%$ of wild falcons in Louisiana (Keymer, 1972) and in $20 \%$ of raptors in Azerbaidzhan, associated with signs such as diarrhea and weight loss (Heidenreich, 1997) Moreover, the death of a Lanner falcon ( F. biarmicus) had been attributed to the acanthocephalan worm Polymorphus boschadis (Keymer, 1972).

A specific therapy has not been established yet, although other avian species have been treated with fenbendazole at a dose of $20 \mathrm{mg} / \mathrm{kg}$ for five days (Heidenreich, 1997). Treatment with ivermectin (Ivomec ${ }^{\circledR}$, Merial) at a dose of $2 \mathrm{mg} / \mathrm{kg}$ is apparently safe (Lierz, 2001) and highly effective in raptors. In these two Saker falcons, concomitant remission of clinical signs and disappearance of eggs from fecal samples soon after administration of an eligible therapy are indirectly diagnostic

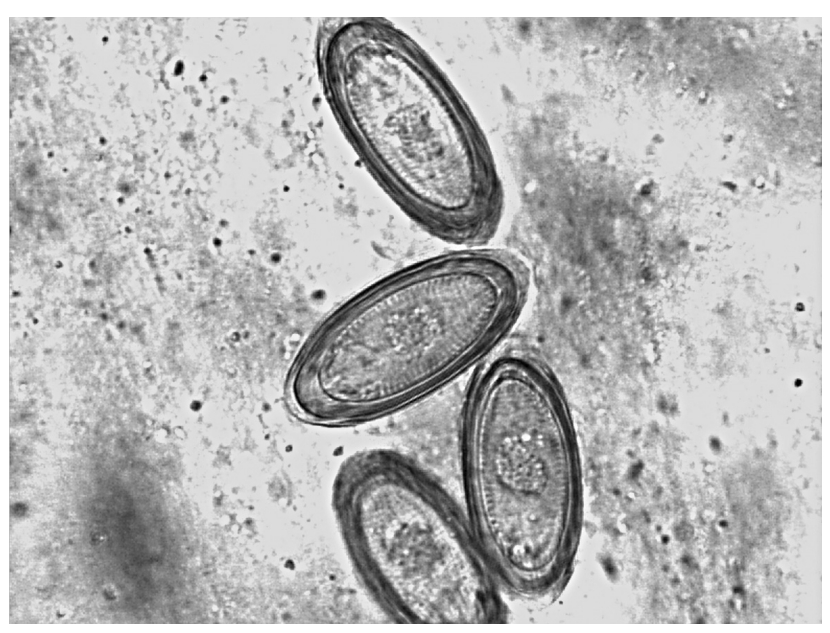

Fig. 1. - Eggs of acanthocephalans $(\times 40)$ from a saker falcon $(n=1)$ with heavy infestation. 


\begin{tabular}{|c|c|c|c|c|}
\hline No. & $\begin{array}{l}\text { Species, sex, age, weight } \\
\text { origin, site and date of visit }\end{array}$ & $\begin{array}{l}\text { Duration } \\
\text { of the disease }\end{array}$ & Clinical findings & $\begin{array}{l}\text { Therapy outcomes } \\
10 \text { days later }\end{array}$ \\
\hline 1 & $\begin{array}{l}\text { Saker, F, } 1 \text { year, } 820 \text { gr, from Iran, } \\
\text { Kuwait, May } 2004\end{array}$ & 7 days & $\begin{array}{l}\text { Poor appetite, weight loss, vomiting } \\
\text { collapse, loss of balance, ruffled } \\
\text { feathers }\end{array}$ & $\begin{array}{l}\text { Complete clinical recovery } \\
\text { Faeces check = negative }\end{array}$ \\
\hline 2 & $\begin{array}{l}\text { Saker, F, } 2 \text { years, } 1,085 \text { gr, unknown, } \\
\text { Dubai, March } 2006\end{array}$ & 3 days & $\begin{array}{l}\text { Poor appetite, weight loss, vomiting } \\
\text { diarrhoea and poor performances }\end{array}$ & $\begin{array}{l}\text { Complete clinical recovery } \\
\text { Faeces check }=\text { negative }\end{array}$ \\
\hline
\end{tabular}

Table I. - Signalment, clinical findings and results of therapy with ivermectin (Ivomec ${ }^{\circledR}$, Merial, $2 \mathrm{mg} / \mathrm{kg}$, im.) in two falcons diagnosed with Acanthocephalan worms.

for the elimination of adult stages and seem to confirm the pathogenicity of acanthocephalans when occurring as sole infesting agents.

\section{REFERENCES}

COOPER J.E. Birds of prey. Health and Disease. $3^{\text {rd }}$ eds. Blackwell Publishing, Oxford, UK, 2005, 120.

Ferrer D., Molina R., Adelantado C. \& Kinsella J.M. Helminths isolated from the digestive tract of diurnal raptors in Catalonia, Spain. Veterinary Record, 2004, 154, 17-20.

Furmaga S. The helminth fauna of predatory birds (Accipitres and Striges) of the environment of Lublin. Acta Parasitologica Polonica, 1957, 5, 215-287.

Heidenreich M. Parasitic diseases, in: Birds of prey, medicine and management. Blackwell Science, Oxford, UK, 1997, $131-148$

Illescas M.P., Rodriguez M. \& Aranda F. Parasitation of falconiform, strigiform and passeriform (Corvidae) by helminthes in Spain. Research and Reviews in Parasitology, 1993, 53, 129-135.

Keymer I.F. Diseases in birds of prey. Veterinary Record, 1972, 90, 579-594.

Krone O. Endoparasites in free-ranging birds of prey in Germany, in: Lumeij J.T., Remple J.D., Redig P.T., Lierz M. \& Cooper J.E. (eds), Raptor Biomedicine III. Zoological Education Network, Inc., Lake Worth, Florida, USA, 2000, 101116.

LACINA D. \& BIRD D.M. Endoparasites of raptors - A review and an update, in: Lumeij J.T., Remple J.D., Redig P.T., Lierz M. \& Cooper J.E. (eds), Raptor Biomedicine III. Zoological Education Network, Inc., Lake Worth, Florida, USA, 2000, 65-78.

LIERz M. Evaluation of the dosage of ivermectin in falcons. Veterinary Record, 2001, 148, 596-600.

MichaleK J. Record of Physaloptera alata and Centrorbynchus buteonis in Falconiformes in Czechoslovakia. Folia Parasitologica, 1984, 31, 383-384.

Sanmartin M.L., Alvarez F., Barreiro G. \& Leiro J. Helminth fauna of Falconiform and Strigiform birds of prey in Gali- cia, Northwest Spain. Parasitology Research, 2004, 92, 255263.

SмiтH S.A. Parasites of birds of prey: their diagnosis and treatment. Seminars in Avian and Exotic Pet Medicine, 1996, 5 (2), 97-105.

Reçu le 23 septembre 2008 Accepté le 10 décembre 2008 